\title{
Production of Biomass-Degrading Multienzyme Complexes under Solid-State Fermentation of Soybean Meal Using a Bioreactor
}

\author{
Gabriela L. Vitcosque, ${ }^{1}$ Rafael F. Fonseca, ${ }^{1}$ Ursula Fabiola Rodríguez-Zúñiga, ${ }^{1}$ \\ Victor Bertucci Neto, ${ }^{1}$ Sonia Couri, ${ }^{2}$ and Cristiane S. Farinas ${ }^{1}$ \\ ${ }^{1}$ Embrapa Instrumentação, Rua XV de Novembro 1452, 13560-970 São Carlos, SP, Brazil \\ ${ }^{2}$ Instituto Federal de Educação, Ciência e Tecnologia do Rio de Janeiro, Rua Senador Furtado 121, Maracanã 20270-021, RJ, Brazil \\ Correspondence should be addressed to Cristiane S. Farinas, cristiane@cnpdia.embrapa.br
}

Received 23 August 2012; Revised 3 December 2012; Accepted 4 December 2012

Academic Editor: Munishwar Nath Gupta

Copyright (C) 2012 Gabriela L. Vitcosque et al. This is an open access article distributed under the Creative Commons Attribution License, which permits unrestricted use, distribution, and reproduction in any medium, provided the original work is properly cited.

\begin{abstract}
Biomass-degrading enzymes are one of the most costly inputs affecting the economic viability of the biochemical route for biomass conversion into biofuels. This work evaluates the effects of operational conditions on biomass-degrading multienzyme production by a selected strain of Aspergillus niger. The fungus was cultivated under solid-state fermentation (SSF) of soybean meal, using an instrumented lab-scale bioreactor equipped with an on-line automated monitoring and control system. The effects of air flow rate, inlet air relative humidity, and initial substrate moisture content on multienzyme (FPase, endoglucanase, and xylanase) production were evaluated using a statistical design methodology. Highest production of FPase $(0.55 \mathrm{IU} / \mathrm{g})$, endoglucanase $(35.1 \mathrm{IU} / \mathrm{g})$, and xylanase $(47.7 \mathrm{IU} / \mathrm{g})$ was achieved using an initial substrate moisture content of $84 \%$, an inlet air humidity of $70 \%$, and a flow rate of $24 \mathrm{~mL} / \mathrm{min}$. The enzymatic complex was then used to hydrolyze a lignocellulosic biomass, releasing $4.4 \mathrm{~g} / \mathrm{L}$ of glucose after 36 hours of saccharification of $50 \mathrm{~g} / \mathrm{L}$ pretreated sugar cane bagasse. These results demonstrate the potential application of enzymes produced under SSF, thus contributing to generate the necessary technological advances to increase the efficiency of the use of biomass as a renewable energy source.
\end{abstract}

\section{Introduction}

Biomass-degrading enzymes are one of the most costly inputs affecting the economic viability of the biochemical route for biomass conversion into biofuels. This is due to the large scale of the processes involved in biofuel production, and the considerable quantities of enzymes that are required. In addition to quantity, the quality of the enzymatic complex is an important issue, since a cocktail containing cellulases, hemicellulases, pectinases, and other accessory enzymes, acting in synergy in the degradation process, is necessary due to the high recalcitrance of plant biomass. This enzymatic complex is produced by a wide variety of microorganisms (bacteria and fungi); however, the aerobic fungi are known for their higher growth and protein secretion rates $[1,2]$. Most commercial cellulases are produced by filamentous fungi of the genera Trichoderma and Aspergillus [3].
The use of solid-state fermentation (SSF) is particularly advantageous for enzyme production by filamentous fungi, since it simulates the natural habitat of the microorganisms [4]. From the environmental point of view, the main benefit of SSF is the ability to use agroindustrial waste (sugarcane bagasse, wheat bran, soybean meal, etc.) as a solid substrate that acts as a source of both carbon and energy [5]. However, certain operational limitations of SSF, such as difficulty in controlling the moisture level of the substrate, and avoiding heat build-up, have held back its industrial application. Previous studies have shown the importance of evaluating the influence of process operational parameters on cellulase production by SSF, using controlled conditions of forced aeration and inlet air relative humidity [6].

Brazil is currently the second largest producer of soybeans, after the USA. In the 2009/2010 season, the crop occupied an area of 23.6 million hectares and achieved 
a production of 68.7 million tons [7]. Compared to other crops, soybeans are the third most heavily traded crop in the world. As demand continues to grow, both production areas and trade are likely to increase more rapidly for soybeans than for most other major crops [8]. Soybean meal, the byproduct remaining after the extraction of oil from whole soybeans, consists of $44 \%$ crude protein, $3.0 \%$ crude fiber, $0.5 \%$ fat, and $12 \%$ moisture [9]. Given its protein-rich composition, this agricultural by-product has considerable potential as a substrate for fungal growth under SSF.

Studies concerning the selection of cultivation conditions for enzyme production by SSF of soybean meal have been described in the literature. The enzymes considered include xylanase [10-12] and cellulase [13, 14], amongst others [15-18]. However, all these studies have been carried out under static cultivation conditions. Therefore, there is great interest in the development of biomass-degrading enzyme production processes using SSF of soybean meal under controlled conditions of forced aeration and inlet air relative humidity.

The present work investigates the effects of operational conditions on the production of biomass-degrading multienzyme complexes (containing FPase, endoglucanase, and xylanase) by a selected strain of Aspergillus niger, cultivated under SSF of soybean meal using an instrumented lab-scale bioreactor. Statistical experimental design, with response surface analysis, was used to study the influence of air flow rate, inlet air relative humidity, and initial substrate moisture content on the efficiency of multienzyme production. The enzymatic complex produced under optimized conditions was used to hydrolyze a lignocellulosic biomass (pretreated sugar cane bagasse).

\section{Materials and Methods}

2.1. Instrumented Bioreactor. The bioreactor used in the fermentations was a lab-scale system adapted from [19], consisting of 16 columns ( $2.5 \mathrm{~cm}$ diameter, $20 \mathrm{~cm}$ length) placed in a water bath. The bioreactor was equipped with an on-line system to control the air flow rate and the inlet air relative humidity, whose description and schematic diagram have been previously reported [6].

2.2. Microorganism. The microorganism used in this study was a strain of $A$. niger (known as A. niger 12), from the Embrapa Food Technology collection (Rio de Janeiro, Brazil), which had been isolated from black pepper [20]. The culture was maintained in PDA slants at $32^{\circ} \mathrm{C}$ for 5 days before inoculation.

2.3. SSF Cultivation Conditions. Fermentations were carried out for 72 hours at $32^{\circ} \mathrm{C}$, using soybean meal as solid substrate, with a moisture level varying from 56 to $84 \%$, according to the experimental design conditions described in Section 2.4. The moisture content was adjusted with a solution of $0.9 \%(\mathrm{w} / \mathrm{v})$ ammonium sulfate in $0.1 \mathrm{~mol} / \mathrm{L} \mathrm{HCl}$. The solid medium was sterilized by autoclaving at $121^{\circ} \mathrm{C}$ for
20 minutes before inoculation. A spore suspension volume corresponding to $10^{7}$ conidia/g of dry solid medium was inoculated into the solid medium by gently stirring with a glass rod until a uniform mixture was obtained. The air flow rate and inlet air relative humidity were varied in the ranges $12-36 \mathrm{~mL} / \mathrm{min}$ and $56-84 \%$, respectively, according to the experimental design described in Section 2.4.

After the cultivation period, the solid medium was transferred to Erlenmeyer flasks, and the enzymes were extracted by adding a sufficient volume of $0.2 \mathrm{~mol} / \mathrm{L}$ sodium acetate buffer, at $\mathrm{pH} 4.5$, to achieve a solid/liquid ratio of $1: 5$. The suspension was stirred at $120 \mathrm{rpm}$ for 30 minutes at $32^{\circ} \mathrm{C}$, and the enzymatic solution was recovered by filtration. The enzyme extracts were stored at $-18^{\circ} \mathrm{C}$ prior to the analyses.

2.4. Experimental Designs. A full factorial design was initially used to evaluate the effects of air flow rate, inlet air relative humidity, and initial substrate moisture content on the efficiency of multienzyme production (as FPase, endoglucanase, and xylanase activities). The experimental design selected was a $2^{3}$ full factorial design comprising eleven runs, corresponding to eight axial points and three central points, with the experiments carried out in random order. Values of the independent variables and their coded levels are given in Table 1. The significant parameters identified by the full factorial design were then optimized using a response surface methodology (RSM). The central composite design (CCD) used consisted of eleven runs, corresponding to four cube points, four axial points, and three central points (Table 3). The response variables were the enzymatic activities of FPase, endoglucanase, and xylanase. The Statsoft (v. 7.0) statistical software package was used for analysis of the experimental data, application of ANOVA (analysis of variance), and generation of the response surfaces. A secondorder polynomial model was used to fit the data:

$$
Y=\beta_{0}+\beta_{1} X_{1}+\beta_{2} X_{2}+\beta_{11} X_{1}^{2}+\beta_{22} X_{2}^{2}+\beta_{12} X_{1} X_{2},
$$

where $Y$ is the predicted response for enzymatic activity, expressed as IU/g; $\beta_{0}$ is the intercept term; $\beta_{1}$ and $\beta_{2}$ are the linear coefficients; $\beta_{11}$ and $\beta_{22}$ are the squared coefficients; $\beta_{12}$ is the interaction coefficient; and $X_{1}$ and $X_{2}$ are the coded independent variables. The terms that were not statistically significant were removed from the model and added to the lack of fit.

2.5. Multienzyme Production Profile. The multienzyme production efficiency was evaluated during a 96-hour cultivation period, using the operational conditions selected in the experimental design (air flow rate of $24 \mathrm{~mL} / \mathrm{min}$, inlet air relative humidity of $70 \%$, and initial substrate moisture content of $84 \%)$. Samples were withdrawn at 24-hour intervals, and the enzymes were extracted and analyzed as described in Section 2.7. A respirometric analysis was carried out by measuring $\mathrm{CO}_{2}$ in the outlet air stream, using a GMM 220 instrument (Vaisala, Finland). The cumulative amount of $\mathrm{CO}_{2}$ produced was calculated from the area under the $\mathrm{CO}_{2}$ versus cultivation time curve. 
TABLE 1: Full factorial design for multienzyme production under different operational conditions.

\begin{tabular}{|c|c|c|c|c|c|c|}
\hline \multirow[b]{2}{*}{ Run } & \multicolumn{3}{|c|}{ Levels } & \multicolumn{3}{|c|}{ Responses } \\
\hline & $\begin{array}{l}\text { Inlet air relative } \\
\text { humidity }(\%)\end{array}$ & $\begin{array}{l}\text { Flow rate } \\
(\mathrm{mL} / \mathrm{min})\end{array}$ & $\begin{array}{l}\text { Substrate initial } \\
\text { moisture }(\%)\end{array}$ & FPase (IU/g) & $\begin{array}{l}\text { Endoglucanase } \\
\text { (IU/g) }\end{array}$ & Xylanase (IU/g) \\
\hline 1 & $-1(60)$ & $-1(12)$ & $-1(60)$ & 0.21 & 29.9 & 48.8 \\
\hline 2 & $1(80)$ & $-1(12)$ & $-1(60)$ & 0.19 & 32.8 & 47.9 \\
\hline 3 & $-1(60)$ & $1(36)$ & $-1(60)$ & 0.20 & 27.5 & 48.2 \\
\hline 4 & $1(80)$ & $1(36)$ & $-1(60)$ & 0.13 & 30.1 & 44.6 \\
\hline 5 & $-1(60)$ & $-1(12)$ & $1(80)$ & 0.23 & 31.2 & 49.3 \\
\hline 6 & $1(80)$ & $-1(12)$ & $1(80)$ & 0.23 & 37.5 & 48.9 \\
\hline 7 & $-1(60)$ & $1(36)$ & $1(80)$ & 0.23 & 30.7 & 50.7 \\
\hline 8 & $1(80)$ & $1(36)$ & $1(80)$ & 0.16 & 38.0 & 50.6 \\
\hline 9 & $0(70)$ & $0(24)$ & $0(70)$ & 0.21 & 40.7 & 51.8 \\
\hline 10 & $0(70)$ & $0(24)$ & $0(70)$ & 0.17 & 42.6 & 53.7 \\
\hline 11 & $0(70)$ & $0(24)$ & $0(70)$ & 0.18 & 40.8 & 51.2 \\
\hline
\end{tabular}

2.6. Hydrolysis Experiments. Crude enzymatic extracts, produced under the optimized conditions, were used to hydrolyze a lignocellulosic biomass (steam-exploded sugarcane bagasse, donated by a local sugarcane mill and characterized according to [21]). The pretreated bagasse was washed, dried at ambient temperature, milled, and sieved to obtain a particle size of $<1 \mathrm{~mm}$. The enzymatic preparations were diluted in $\mathrm{pH} 4.8$ citrate buffer, and the enzymes were loaded at a rate of $5 \mathrm{FPU} / \mathrm{g}$ of dry material. The experiments were carried out for 36 hours at $50^{\circ} \mathrm{C}$, in $125 \mathrm{~mL}$ Erlenmeyer flasks containing $1.5 \mathrm{~g}$ of bagasse and a total liquid volume of $30 \mathrm{~mL}$, with $200 \mathrm{rpm}$ agitation. Samples were collected after defined time intervals, and the concentrations of glucose, xylose, and cellobiose were determined using HPLC [21]. Total reducing groups were quantified according to the DNS method developed by Miller [22].

2.7. Multienzyme Activity Assays. The activities of FPase and endoglucanase were measured according to the methodology described by Ghose [23]. Here, one unit of activity corresponds to $1 \mu \mathrm{mol}$ of glucose released per minute, at $\mathrm{pH} 4.8$ and $50^{\circ} \mathrm{C}$. Xylanase activity was measured by the method described by Bailey and Poutanen [24]. One unit of xylanase activity corresponds to $1 \mu \mathrm{mol}$ of xylose released per minute, at $\mathrm{pH} 5.0$ and $50^{\circ} \mathrm{C}$. The results were expressed as activity units per mass of initial dry solid substrate (IU/g).

\section{Results and Discussion}

3.1. Influence of SSF Operational Conditions on Multienzyme Production. Biomass-degrading enzymes are present in the form of multienzyme systems whose components have a synergistic action during degradation of the polymeric chains of lignocellulosic materials. Here, a $2^{3}$ full factorial design was used first to determine the effects of inlet air relative humidity, air flow rate, and initial substrate moisture content on the efficiency of multienzyme production by $A$. niger grown on soybean meal under SSF. Table 1 presents the experimental conditions and the responses for FPase, endoglucanase, and xylanase production. FPase activity values ranged from 0.13 (run 4) to $0.23 \mathrm{IU} / \mathrm{g}$ (runs 5, 6, and 7), endoglucanase activity ranged from 27.5 (run 3 ) to $42.6 \mathrm{IU} / \mathrm{g}$ (run 10), and xylanase activity ranged from 47.9 (run 2) to $53.7 \mathrm{IU} / \mathrm{g}$ (run 10).

The data were analyzed to determine the effect of each variable (Table 2). Each enzyme showed different behavior in terms of the influence of the operational conditions. All three independent variables showed a statistically significant influence on FPase activity, within a confidence limit of $90 \%$. Inlet air relative humidity and air flow rate showed negative effects, while initial substrate moisture content showed a positive effect on FPase production, within the range tested. For endoglucanase, both inlet air relative humidity and initial substrate moisture content showed significant positive influences, within a confidence limit of $95 \%$. None of the variables showed any significant influence on xylanase production, within the ranges tested.

Based on the statistical results, a new factorial design was drawn up in order to implement the optimization of the variables. The ranges of the inlet air relative humidity and initial substrate moisture content were expanded to 56$84 \%$, taking into consideration the saturation limit of the substrate. Since the air flow rate showed no significant effect on the activity of either endoglucanase or xylanase, within the range tested, this variable was fixed at the central point value used previously $(24 \mathrm{~mL} / \mathrm{min})$.

3.2. Optimization of Multienzyme Production. The significant parameters identified using the $2^{3}$ full factorial design were further optimized using a response surface methodology (RSM). In this procedure, the effects of inlet air relative humidity and initial substrate moisture content on multienzyme production efficiency were studied using a central composite design (CCD). Table 3 presents the experimental conditions and the responses for FPase, endoglucanase, and xylanase production. FPase activity values ranged from 0.07 (run 5) to $0.22 \mathrm{IU} / \mathrm{g}$ (runs 3 and 4), endoglucanase activity ranged from 30.2 (runs 2 and 7) to $39.3 \mathrm{IU} / \mathrm{g}$ (run 8), and 
TABLE 2: Effects of independent variables on multienzyme activity, based on $2^{3}$ full factorial design experiments.

\begin{tabular}{|c|c|c|c|c|c|c|}
\hline & \multicolumn{2}{|c|}{ FPase } & \multicolumn{2}{|c|}{ Endoglucanase } & \multicolumn{2}{|c|}{ Xylanase } \\
\hline & Effect & $P$ value & Effect & $P$ value & Effect & $P$ value \\
\hline Mean & $0.195^{* *}$ & 0.000 & $34.711^{*}$ & 0.000 & $49.621^{*}$ & 0.000 \\
\hline (1) Inlet air relative humidity & $-0.041^{* *}$ & 0.033 & $4.762^{*}$ & 0.023 & -1.270 & 0.293 \\
\hline (2) Flow rate & $-0.034^{* *}$ & 0.054 & -1.263 & 0.230 & -0.175 & 0.864 \\
\hline (3) Substrate initial moisture & $0.033^{* *}$ & 0.060 & $4.259^{*}$ & 0.029 & 2.487 & 0.109 \\
\hline $1 \times 2$ & $-0.030^{* *}$ & 0.080 & 0.198 & 0.814 & -0.601 & 0.572 \\
\hline $1 \times 3$ & 0.003 & 0.801 & 2.038 & 0.110 & 0.996 & 0.383 \\
\hline $2 \times 3$ & -0.003 & 0.824 & 1.247 & 0.234 & 1.757 & 0.190 \\
\hline$R$ & \multicolumn{2}{|c|}{0.88211} & \multicolumn{2}{|c|}{0.34182} & \multicolumn{2}{|c|}{0.42923} \\
\hline
\end{tabular}

${ }^{*}$ Significant at 0.05 level; ${ }^{*}$ Significant at 0.1 level; $R$ : coefficient of determination.

xylanase activity ranged from 30.9 (run 6) to $51.1 \mathrm{IU} / \mathrm{g}$ (run 4).

Application of analysis of variance (ANOVA) to the multienzyme production results (Table 4 ) gave a correlation coefficient of 0.7748 and an $F$ value of 13.76 (3.09-fold higher than the listed $F$ value, at a 95\% confidence level) for endoglucanase activity. These values were satisfactory for prediction using the model ((1), with the coefficients listed in Table 4) employed to describe the response surface plot for endoglucanase production (Figure 1). For FPase and xylanase, it was not possible to obtain a quadratic model that represented the process, since the $F$ values and correlation coefficients were both low in the case of these enzymes.

At a fixed air flow rate of $24 \mathrm{~mL} / \mathrm{min}$, higher endoglucanase production $(39.3 \mathrm{IU} / \mathrm{g})$ by $A$. niger was obtained using an inlet air relative humidity of $70 \%$ and an initial substrate moisture content of $84 \%$. Under these conditions, the activities of FPase and xylanase were 0.20 and $41.6 \mathrm{IU} / \mathrm{g}$, respectively. In previous work, endoglucanase production of up to $56.1 \mathrm{IU} / \mathrm{g}$ was achieved using wheat bran as solid substrate [6]. Even though lower endoglucanase production was obtained in the present study, both values are of the same order of magnitude. A comparison between the composition of soybean meal and wheat bran is presented in Table 5. Although soybean meal has a higher protein and cellulose content than wheat bran, other characteristics such as higher lignin content and differences in their porosity can be contributing to the lower enzymatic production values achieved by $A$. niger cultivated in soybean meal.

It is interesting to note that the optimization using CCD did not result in higher multienzyme production values, compared to the full factorial design, indicating that the conditions used in the first experimental design were close to the optimum values. Nevertheless, using CCD it was possible to obtain a quadratic model that represented endoglucanase production and the influence of both inlet air relative humidity and initial substrate moisture content on the SSF process.

The initial substrate moisture content, as well as the aeration rate, was shown by Spier et al. [39] to exert a significant influence on phytase production by $A$. niger cultivated in a column-type SSF bioreactor. Among the various operational parameters that affect SSF process efficiency, moisture

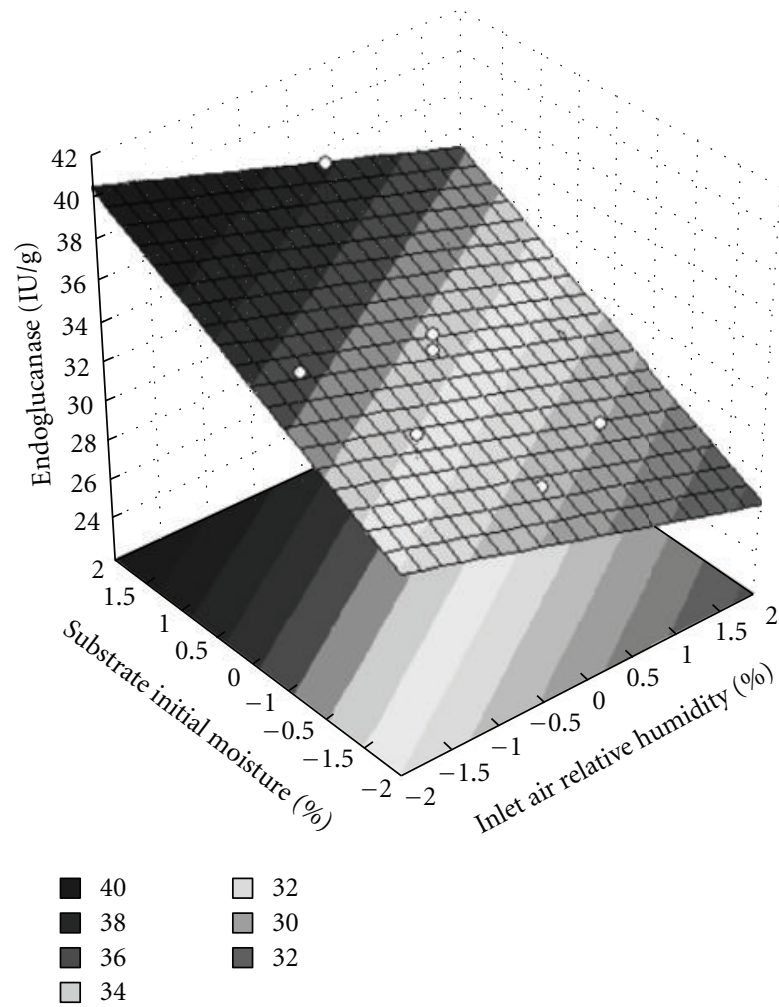

Figure 1: Response surface plot for the effects of initial substrate moisture content and inlet air relative humidity on endoglucanase activity.

content is one of the most important. If the moisture content is too high, the void spaces in the solids are filled with water, resulting in oxygen limitation. At the other extreme, if the moisture content is too low, the growth of the microorganism will be hindered [40]. Consequently, identification of the optimal moisture content for each solid substrate is crucial for the promotion of favorable growing conditions, and hence for satisfactory metabolite production. However, the optimal moisture content value depends on both the solid substrate and the microorganism used [5].

The effect of the initial substrate moisture content on the production of cellulase using SSF has also been described 
TABle 3: Central composite design for multienzyme production under different inlet air relative humidity and initial substrate moisture content conditions.

\begin{tabular}{|c|c|c|c|c|c|}
\hline \multirow[b]{2}{*}{ Run } & \multicolumn{2}{|c|}{ Levels } & \multicolumn{3}{|c|}{ Enzymes (IU/g) } \\
\hline & $\begin{array}{l}\text { Inlet air relative } \\
\text { humidity }(\%)\end{array}$ & $\begin{array}{c}\text { Substrate initial } \\
\text { moisture }(\%)\end{array}$ & FPase & Endoglu-canase & Xylanase \\
\hline 1 & $-1(60)$ & $-1(60)$ & 0.18 & 33.9 & 42.0 \\
\hline 2 & $+1(80)$ & $-1(60)$ & 0.15 & 30.2 & 42.0 \\
\hline 3 & $-1(60)$ & $+1(80)$ & 0.22 & 34.9 & 48.6 \\
\hline 4 & $+1(80)$ & $+1(80)$ & 0.22 & 33.4 & 51.1 \\
\hline 5 & $-1,41(56)$ & $0(70)$ & 0.07 & 35.2 & 39.2 \\
\hline 6 & $1.41(84)$ & $0(70)$ & 0.16 & 31.2 & 30.9 \\
\hline 7 & $0(70)$ & $-1,41(56)$ & 0.20 & 30.2 & 49.8 \\
\hline 8 & $0(70)$ & $1.41(84)$ & 0.20 & 39.3 & 41.6 \\
\hline 9 & $0(70)$ & $0(70)$ & 0.16 & 34.2 & 40.9 \\
\hline 10 & $0(70)$ & $0(70)$ & 0.13 & 33.1 & 38.1 \\
\hline 11 & $0(70)$ & $0(70)$ & 0.09 & 33.4 & 39.3 \\
\hline
\end{tabular}

TABLE 4: Values of coefficients, and statistical analysis of multienzyme activity, based on central composite design experiments.

\begin{tabular}{|c|c|c|c|c|c|c|}
\hline & \multicolumn{2}{|c|}{ FPase } & \multicolumn{2}{|c|}{ Endoglucanase } & \multicolumn{2}{|c|}{ Xylanase } \\
\hline & Coefficient & $P$ value & Coefficient & $P$ value & Coefficient & $P$ value \\
\hline Mean & $0.13^{* *}$ & 0.025 & $33.56^{*}$ & 0.000 & $39.39^{*}$ & 0.000 \\
\hline Inlet air humidity $X_{1}(\mathrm{~L})$ & 0.01 & 0.401 & $-1.35^{*}$ & 0.022 & -1.15 & 0.155 \\
\hline Inlet air humidity $X_{1}(\mathrm{Q})$ & 0.00 & 0.804 & -0.39 & 0.245 & -0.79 & 0.325 \\
\hline Substrate initial moisture $X_{2}(\mathrm{~L})$ & 0.01 & 0.375 & $2.14^{*}$ & 0.009 & 0.53 & 0.410 \\
\hline Substrate initial moisture $X_{2}(\mathrm{Q})$ & $0.05^{* *}$ & 0.092 & 0.37 & 0.268 & $4.57^{*}$ & 0.017 \\
\hline$X_{1}(\mathrm{~L}) \times X_{2}(\mathrm{~L})$ & 0.01 & 0.708 & 0.54 & 0.198 & 0.66 & 0.460 \\
\hline$R$ & 0.61511 & & 0.77479 & & 0.46473 & \\
\hline$F$ value & 1.60 & & 13.76 & & 0.87 & \\
\hline$F_{\text {cal }} / F_{\text {listed }}$ & \multicolumn{2}{|c|}{0.46} & \multicolumn{2}{|c|}{3.09} & \multicolumn{2}{|c|}{0.17} \\
\hline
\end{tabular}

*Significant at 0.05 level; ${ }^{* *}$ Significant at 0.1 level; $R$ : coefficient of determination.

previously. Mamma et al. [32] evaluated enzyme production under SSF, using the fungus $A$. niger with orange peel as substrate, and were able to significantly increase enzyme activities after optimizing the initial moisture content of the solid medium. Gao et al. [25] found that an increase in the initial moisture content enhanced enzyme production by the thermoacidophilic fungus Aspergillus terreus M11, cultivated under SSF using corn stover as substrate.

\subsection{Multienzyme Production Profiles under Selected Condi-} tions. The profiles of multienzyme production over a period of 96 hours, using an initial substrate moisture content of $84 \%$, an inlet air humidity of $70 \%$, and a flow rate of $24 \mathrm{~mL} / \mathrm{min}$ are illustrated in Figure 2. Xylanase production reached its highest value $(47.7 \mathrm{IU} / \mathrm{g})$ after 48 hours of cultivation, whereas the highest values for endoglucanase and FPase (35.1 and $0.55 \mathrm{IU} / \mathrm{g}$, resp.) were only achieved after around 96 hours. The profiles of xylanase and cellulase production during cultivation therefore appeared to be influenced by the presence of the lignocellulosic biomass, with initial production of xylanases in order to degrade the

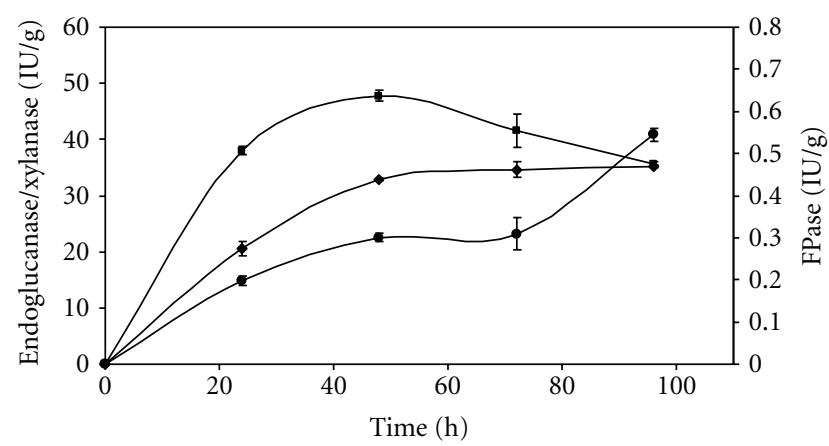

Figure 2: Kinetics of multienzyme production during $A$. niger cultivation in soybean meal at $84 \%$ initial moisture content, with a flow rate of $24 \mathrm{~mL} / \mathrm{min}$ and an inlet air relative humidity of $70 \%$. $(\bullet)$ FPase, $(\bullet)$ endoglucanase, $(\boldsymbol{\square})$ xylanase.

hemicellulosic fraction, followed by production of cellulases for the conversion of cellulose to sugars.

The evolution of $\mathrm{CO}_{2}$ during the SSF process was monitored using a sensor connected to the gas stream exiting the columns. $\mathrm{CO}_{2}$ data can provide an important means of 
TABLE 5: Composition of lignocellulosic materials [13].

\begin{tabular}{|c|c|c|c|c|}
\hline & Cellulose $(\%)$ & Hemicellulose (\%) & Lignin $(\%)$ & Protein $(\%)$ \\
\hline Soybean meal & 34.59 & 18.13 & 9.78 & 43.22 \\
\hline Wheat bran & 10.86 & 28.88 & 4.89 & 17.61 \\
\hline Pretreated sugarcane bagasse & 61.50 & 4.51 & 32.05 & - \\
\hline
\end{tabular}

TABLE 6: Comparison of biomass-degrading enzymes production by Aspergillus strains cultivated under SSF.

\begin{tabular}{|c|c|c|c|c|c|c|}
\hline Organism & Substrate & Incubation time & Xylanase (IU/g) & $\begin{array}{c}\text { Endoglucanase } \\
(\mathrm{IU} / \mathrm{g})\end{array}$ & FPAse (IU/g) & Reference \\
\hline Aspergillus terreus M11 & Corn stover & $96 \mathrm{~h}$ & - & 563 & 231 & {$[25]$} \\
\hline A. niger NS-2 & Wheat bran & $96 \mathrm{~h}$ & - & 310 & 17 & {$[26]$} \\
\hline Aspergillus fumigatus fresenius & Rice straw & 5 days & 2800 & 240.2 & 9.73 & {$[27]$} \\
\hline A. terreus & Rice straw & 7 days & - & 233.7 & 10.96 & {$[28]$} \\
\hline Aspergillus niger NRRL-567 & Apple pomace & $48 \mathrm{~h}$ & 1412.58 & 172.31 & 133.68 & {$[29]$} \\
\hline A. niger $\mathrm{P} 47 \mathrm{C} 3$ & Soybean bran & 5 days & 484.2 & 152 & 5.6 & {$[14]$} \\
\hline A. niger MTCC 7956 & Wheat bran & $72 \mathrm{~h}$ & - & 135.44 & 4.55 & {$[30]$} \\
\hline A. niger $\mathrm{KK} 2$ & Rice straw & 4-6 days & 5070 & 129 & 19.5 & {$[31]$} \\
\hline A. niger BTL & Orange peels & 6 days & 77.1 & 60.5 & - & {$[32]$} \\
\hline A. niger & Wheat bran & $72 \mathrm{~h}$ & - & 56.1 & - & {$[6]$} \\
\hline A. niger & Soybean meal & $96 \mathrm{~h}$ & 47.7 & 35.1 & 0.55 & This work \\
\hline A. niger & Wheat bran & $48 \mathrm{~h}$ & 170 & 30 & 1.13 & {$[33]$} \\
\hline A. nidulans MTCC344 & $\begin{array}{l}\text { Sugarcane } \\
\text { bagasse }\end{array}$ & 8 days & - & 28.96 & - & {$[34]$} \\
\hline A. niger & Wheat bran & $72 \mathrm{~h}$ & - & 21 & 0.4 & {$[13]$} \\
\hline A. humus & $\begin{array}{l}\text { Wheat bran and } \\
\text { rice straw }\end{array}$ & 5 days & 740 & 12.94 & 6.28 & {$[35]$} \\
\hline A. niger & Mango residue & $74 \mathrm{~h}$ & - & 7.26 & 2.55 & {$[36]$} \\
\hline A. awamori & $\begin{array}{l}\text { Grape pomace } \\
\text { and orange peels }\end{array}$ & 10 days & 32 & 5.4 & - & {$[37]$} \\
\hline A. niger 3Т5B8 & Mango peel & $24 \mathrm{~h}$ & 50.82 & - & 8.75 & {$[38]$} \\
\hline A. niger & $\begin{array}{l}\text { Sugarcane } \\
\text { bagasse and } \\
\text { soybean meal }\end{array}$ & $96 \mathrm{~h}$ & 3099 & - & - & {$[10]$} \\
\hline
\end{tabular}

understanding the relationship between fungal growth and enzyme production, since it is difficult to measure biomass in SSF due to the problem of separating the biomass from the substrate [5]. A comparison between endoglucanase production and the cumulative evolution of $\mathrm{CO}_{2}$ during cultivation of $A$. niger is shown in Figure 3. The conditions used were an inlet air relative humidity of $70 \%$, an air flow rate of $24 \mathrm{~mL} / \mathrm{min}$, and an initial substrate moisture content of $84 \% . \mathrm{CO}_{2}$ production correlated well with endoglucanase production $\left(R^{2}=0.9448\right)$. A similar result was obtained in our earlier study of endoglucanase production using wheat bran as solid substrate [6]. It was not possible to obtain any correlations between the cumulative evolution of $\mathrm{CO}_{2}$ and either FPase or xylanase.

The comparisons of cellulase and xylanase activities produced under SSF by other Aspergillus strains showed that the results obtained in this work compared favorably with those reported in the literature, although there are a

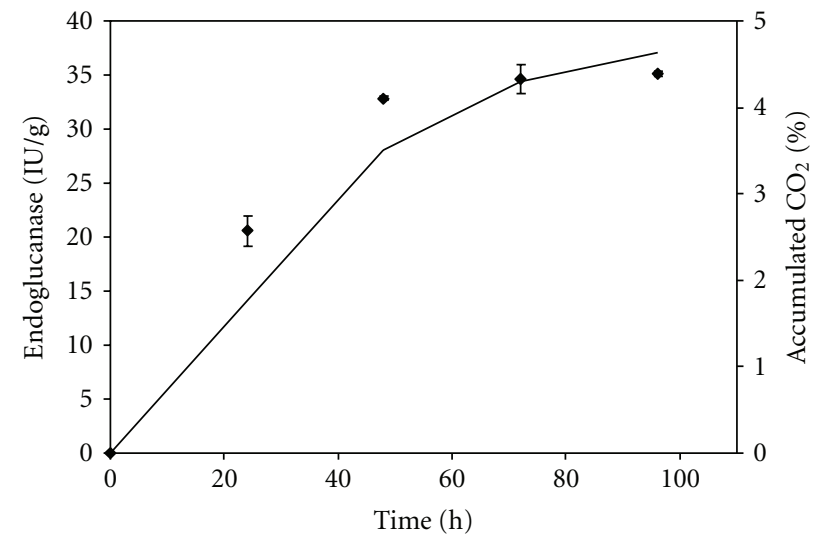

Figure 3: Endoglucanase production kinetics and cumulative $\mathrm{CO}_{2}$ production (full line, left $y$ axis) during $A$. niger cultivation in soybean meal at $84 \%$ initial moisture content, with a flow rate of $24 \mathrm{~mL} / \mathrm{min}$ and an inlet air relative humidity of $70 \%$. 


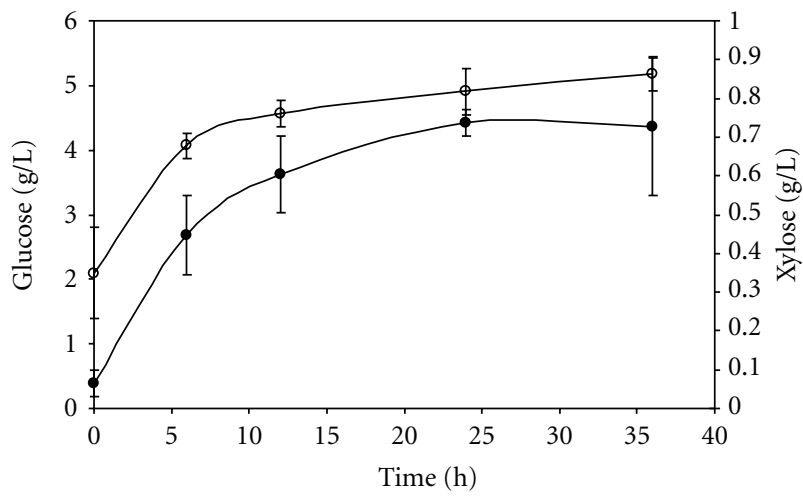

FIgURE 4: Hydrolysis of $5 \%(\mathrm{w} / \mathrm{v})$ steam-pretreated sugarcane bagasse at $\mathrm{pH} 4.8$ and $50^{\circ} \mathrm{C}$, using enzyme cocktails produced during $A$. niger cultivation in soybean meal at $84 \%$ initial moisture content, with a flow rate of $24 \mathrm{~mL} / \mathrm{min}$ and an inlet air relative humidity of $70 \%$. (•) Glucose, $(\bigcirc)$ xylose.

number of superior activity values, specially for xylanase activity (Table 6). However, it should be highlighted that this work was not optimized in terms of xylanase, with this enzyme being usually produced simultaneously by organisms with cellulolytic activities. The sources of variability that should be taken into consideration when analyzing the data presented in Table 6 include the characteristics of the fungal strain (mutation, thermophilicity, and others) as well as the differences in cultivation conditions such as moisture content, temperature, incubation period, and substrate used for SSF. It was also observed that cellulase and xylanase activity assays can vary considerably among laboratories (including substrate, reaction temperature, $\mathrm{pH}$, and time). Therefore, it is difficult to compare yields of enzymes produced by SSF, but values given in Table 6 provide a notion about their order of magnitude and should be used only as a guideline for comparing the different systems reported.

3.4. Hydrolysis Experiments. A set of enzymatic hydrolysis experiments using pretreated sugarcane bagasse were conducted in order to determine the hydrolytic potential of the multienzyme complex produced by $A$. niger cultivated under the optimized conditions identified in the CCD procedure.

The enzyme loading corresponded to $5 \mathrm{FPU} / \mathrm{g}$ of cellulose. Figure 4 illustrates the temporal profiles of the concentrations of glucose and xylose, during saccharification of the pretreated bagasse. Cellobiose was also analyzed, but was not detectable, indicating that there was no accumulation of this compound, probably due to the presence of $\beta$-glucosidase in the enzymatic complex. The amount of glucose released in 36 hours of saccharification was $4.4 \mathrm{~g} / \mathrm{L}$. In terms of the glucose yield after 36 hours of hydrolysis, calculated from the cellulose content of the pretreated bagasse, this value corresponds to a conversion rate of $14.2 \%$.

The nonlinear profile observed for the hydrolysis of the pretreated bagasse was expected due to the heterogeneous nature of the lignocellulosic biomass. As a result, extension of the hydrolysis time beyond 24 hours showed little additional increment in the hydrolysis yield. Such behavior can be explained by the presence of lignin in the pretreated bagasse (Table 5). It has been reported that the presence of lignin impedes the performance of the enzyme during hydrolysis by creating nonproductive enzyme-lignin bonds [41]. Thus, a partial delignification of the pretreated material before enzymatic hydrolysis could possibly lead to higher sugar yields.

The profile of xylose release from pretreated bagasse was also nonlinear (Figure 4), with $0.86 \mathrm{~g} / \mathrm{L}$ being released after 36 hours of hydrolysis. Considering that there was a small concentration of xylose $(0.35 \mathrm{~g} / \mathrm{L})$ in the initial hydrolysis supernatant, which was probably already present in the enzymatic extract, the amount of xylose released was relatively low. Such low concentration of xylose can be explained by the partial removal of the hemicellulosic fraction in the pretreated sugarcane bagasse used (Table 5). Steam explosion, which has been considered a potential pretreatment technology for sugarcane bagasse, extracts the more soluble polymers preventing their subsequent hydrolysis [42].

Gottschalk et al. [43] produced an enzymatic cocktail using A. awamori cultivated under submerged fermentation. Hydrolysis of pretreated sugarcane bagasse using the enzymes produced, at a loading of $10 \mathrm{FPU} / \mathrm{g}$ of solids, resulted in the formation of $3.5 \mathrm{~g} / \mathrm{L}$ of glucose within 72 hours, similar to the value of $4.4 \mathrm{~g} / \mathrm{L}$ obtained here. Overall, the results of the hydrolysis experiments indicated that the enzymatic cocktail produced by $A$. niger has good potential for use in the conversion of biomass.

\section{Conclusions}

The influence of SSF process variables on fungal growth and biomass-degrading multienzyme production was studied using a lab-scale instrumented bioreactor. The results obtained enabled selection of the variables that could be adjusted in order to improve multienzyme production. Highest enzymatic activities were obtained using an initial substrate moisture content of $84 \%$, an inlet air humidity of $70 \%$, and an air flow rate of $24 \mathrm{~mL} / \mathrm{min}$. The enzymatic complex produced under the optimized conditions was used to hydrolyze a lignocellulosic biomass, releasing $4.4 \mathrm{~g} / \mathrm{L}$ of glucose after 36 hours of saccharification of $50 \mathrm{~g} / \mathrm{L}$ pretreated sugar cane bagasse. The enzymatic complex therefore showed good potential for use in biomass conversion.

\section{Acknowledgments}

The authors would like to thank Embrapa, CNPq, and Finep (all from Brazil) for their financial support.

\section{References}

[1] L. R. Lynd, P. J. Weimer, W. H. Van Zyl, and I. S. Pretorius, "Microbial cellulose utilization: fundamentals and biotechnology," Microbiology and Molecular Biology Reviews, vol. 66, no. 3, pp. 506-577, 2002.

[2] D. B. Wilson, "Cellulases and biofuels," Current Opinion in Biotechnology, vol. 20, no. 3, pp. 295-299, 2009. 
[3] Y. H. P. Zhang and L. R. Lynd, "Toward an aggregated understanding of enzymatic hydrolysis of cellulose: noncomplexed cellulase systems," Biotechnology and Bioengineering, vol. 88, no. 7, pp. 797-824, 2004.

[4] U. Hölker and J. Lenz, "Solid-state fermentation-are there any biotechnological advantages?" Current Opinion in Microbiology, vol. 8, no. 3, pp. 301-306, 2005.

[5] M. Raimbault, "General and microbiological aspects of solid substrate fermentation," Electronic Journal of Biotechnology, vol. 1, pp. 3-45, 1998.

[6] C. S. Farinas, G. L. Vitcosque, R. F. Fonseca, V. B. Neto, and S. Couri, "Modeling the effects of solid state fermentation operating conditions on endoglucanase production using an instrumented bioreactor," Industrial Crops and Products, vol. 34, no. 1, pp. 1186-1192, 2011.

[7] Embrapa Soybean, Brazilian Agricultural Research Corporation, 2011, http://www.cnpso.embrapa.br.

[8] G. L. Hartman, E. D. West, and T. K. Herman, "Crops that feed the World 2. Soybean-worldwide production, use, and constraints caused by pathogens and pests," Food Security, vol. 3, no. 1, pp. 5-17, 2011.

[9] Y. Su, X. Zhang, Z. Hou, X. Zhu, X. Guo, and P. Ling, "Improvement of xylanase production by thermophilic fungus Thermomyces lanuginosus SDYKY-1 using response surface methodology," New Biotechnology, vol. 28, no. 1, pp. 40-46, 2011.

[10] G. M. Maciel, L. P. D. S. Vandenberghe, C. W. I. Haminiuk et al., "Xylanase production by Aspergillus niger LPB 326 in solidstate fermentation using statistical experimental designs," Food Technology and Biotechnology, vol. 46, no. 2, pp. 183-189, 2008.

[11] G. M. MacIel, L. P. De Souza Vandenberghe, R. C. Fendrich, B. E. Della, C. W. I. Haminiuk, and C. R. Soccol, "Study of some parameters which affect xylanase production: strain selection, enzyme extraction optimization, and influence of drying conditions," Biotechnology and Bioprocess Engineering, vol. 14, no. 6, pp. 748-755, 2009.

[12] J. X. Heck, S. H. Flôres, P. F. Hertz, and M. A. Z. Ayub, "Statistical optimization of thermo-tolerant xylanase activity from Amazon isolated Bacillus circulans on solid-state cultivation," Bioresource Technology, vol. 97, no. 15, pp. 1902-1906, 2006.

[13] U. F. Rodríguez-Zúñiga, C. S. Farinas, V. B. Neto, S. Couri, and S. Crestana, "Aspergillus niger production of cellulases by solid-state fermentation," Pesquisa Agropecuaria Brasileira, vol. 46, no. 8, pp. 912-919, 2011.

[14] P. D. S. Delabona, R. D. P. B. Pirota, C. A. Codima, C. R. Tremacoldi, A. Rodrigues, and C. S. Farinas, "Effect of initial moisture content on two Amazon rainforest Aspergillus strains cultivated on agro-industrial residues: biomass-degrading enzymes production and characterization," Industrial Crops and Products, vol. 42, no. 1, pp. 236-242, 2013.

[15] L. D. de Paris, F. B. Scheufele, A. T. Júnior, T. L. Guerreiro, and S. D. M. Hasan, "Enzyme complexes production by A. niger from soybean under solid state fermentation," Acta Scientiarum, vol. 34, no. 2, pp. 193-200, 2012.

[16] E. Rigo, J. L. Ninow, M. Di Luccio et al., "Lipase production by solid fermentation of soybean meal with different supplements," LWT-Food Science and Technology, vol. 43, no. 7, pp. 1132-1137, 2010.

[17] G. D. P. Vargas, H. Treichel, D. de Oliveira, S. C. Beneti, D. M. G. Freire, and M. Di Luccio, "Optimization of lipase production by Penicillium simplicissimum in soybean meal," Journal of Chemical Technology and Biotechnology, vol. 83, no. 1, pp. 47-54, 2008.
[18] C. Q. Liu, Q. H. Chen, B. Tang, H. Ruan, and G. Q. He, "Response surface methodology for optimizing the fermentation medium of alpha-galactosidase in solid-state fermentation," Letters in Applied Microbiology, vol. 45, no. 2, pp. 206212, 2007.

[19] R. Raimbault and J. C. Germon, "Procédé d'enrichissement en protéines de produits comestibles solides," French Patent 7606-677, 1976.

[20] S. Couri and A. X. Farias, "Genetic manipulation of Aspergillus niger for increased synthesis of pectinolytic enzymes," Revista de Microbiologia, vol. 26, pp. 314-317, 1995.

[21] E. R. Gouveia, R. T. D. Nascimento, A. M. Souto-Maior, and G. J. M. De Rocha, "Validation of methodology for the chemical characterization of sugar cane bagasse," Quimica Nova, vol. 32, no. 6, pp. 1500-1503, 2009.

[22] G. L. Miller, "Use of dinitrosalicylic acid reagent for determination of reducing sugar," Analytical Chemistry, vol. 31, no. 3, pp. 426-428, 1959.

[23] T. K. Ghose, "Measurement of cellulase activities," Pure and Applied Chemistry, vol. 59, pp. 257-268, 1987.

[24] M. J. Bailey and K. Poutanen, "Production of xylanolytic enzymes by strains of Aspergillus," Applied Microbiology and Biotechnology, vol. 30, no. 1, pp. 5-10, 1989.

[25] J. Gao, H. Weng, D. Zhu, M. Yuan, F. Guan, and Y. Xi, "Production and characterization of cellulolytic enzymes from the thermoacidophilic fungal Aspergillus terreus M11 under solidstate cultivation of corn stover," Bioresource Technology, vol. 99, no. 16, pp. 7623-7629, 2008.

[26] N. Bansal, R. Tewari, R. Soni, and S. K. Soni, "Production of cellulases from Aspergillus niger NS-2 in solid state fermentation on agricultural and kitchen waste residues," Waste Management, vol. 32, no. 7, pp. 1341-1346, 2012.

[27] R. Soni, A. Nazir, and B. S. Chadha, "Optimization of cellulase production by a versatile Aspergillus fumigatus fresenius strain (AMA) capable of efficient deinking and enzymatic hydrolysis of Solka floc and bagasse," Industrial Crops and Products, vol. 31, no. 2, pp. 277-283, 2010.

[28] M. Narra, G. Dixit, and A. R. Shah, "Production of cellulases by solid state fermentation with Aspergillus terreus and enzymatic hydrolysis of mild alkali-treated rice straw," Bioresource Technology, vol. 121, pp. 355-361, 2012.

[29] G. S. Dhillon, S. Kaur, S. K. Brar, and M. Verma, "Potential of apple pomace as a solid substrate for fungal cellulase and hemicellulase bioproduction through solid-state fermentation," Industrial Crops and Products, vol. 38, no. 1, pp. 6-13, 2012.

[30] R. K. Sukumaran, R. R. Singhania, G. M. Mathew, and A. Pandey, "Cellulase production using biomass feed stock and its application in lignocellulose saccharification for bio-ethanol production," Renewable Energy, vol. 34, no. 2, pp. 421-424, 2009.

[31] S. W. Kang, Y. S. Park, J. S. Lee, S. I. Hong, and S. W. Kim, "Production of cellulases and hemicellulases by Aspergillus niger KK2 from lignocellulosic biomass," Bioresource Technology, vol. 91, no. 2, pp. 153-156, 2004.

[32] D. Mamma, E. Kourtoglou, and P. Christakopoulos, "Fungal multienzyme production on industrial by-products of the citrus-processing industry," Bioresource Technology, vol. 99, no. 7, pp. 2373-2383, 2008.

[33] M. C. T. Damaso, S. C. Terzi, M. E. Fraga, and S. Couri, "Selection of cellulolytic fungi isolated from diverse substrates," Brazilian Archives of Biology and Technology, vol. 55, no. 4, pp. 513-520, 2012. 
[34] S. Anuradha Jabasingh and C. Valli Nachiyar, "Utilization of pretreated bagasse for the sustainable bioproduction of cellulase by Aspergillus nidulans MTCC344 using response surface methodology," Industrial Crops and Products, vol. 34, no. 3, pp. 1564-1571, 2011.

[35] T. R. Shamala and K. R. Sreekantiah, "Production of cellulases and D-xylanase by some selected fungal isolates," Enzyme and Microbial Technology, vol. 8, no. 3, pp. 178-182, 1986.

[36] T. C. dos Santos, N. B. Santana, and M. Franco, "Optimization of productions of cellulolytic enzymes by Aspergillus niger using residue of mango a substrate," Ciencia Rural, vol. 41, no. 12, pp. 2210-2216, 2011.

[37] C. S. Farinas, M. M. Loyo, A. Baraldo, P. W. Tardioli, V. B. Neto, and S. Couri, "Finding stable cellulase and xylanase: evaluation of the synergistic effect of $\mathrm{pH}$ and temperature," New Biotechnology, vol. 27, no. 6, pp. 810-815, 2010.

[38] S. Couri, S. Da Costa Terzi, G. A. Saavedra Pinto, S. Pereira Freitas, and A. C. Augusto Da Costa, "Hydrolytic enzyme production in solid-state fermentation by Aspergillus niger 3T5B8," Process Biochemistry, vol. 36, no. 3, pp. 255-261, 2000.

[39] M. R. Spier, A. L. Woiciechowski, L. A. J. Letti et al., "Monitoring fermentation parameters during phytase production in column-type bioreactor using a new data acquisition system," Bioprocess and Biosystems Engineering, vol. 33, no. 9, pp. 10331041, 2010.

[40] K. S. M. S. Raghavarao, T. V. Ranganathan, and N. G. Karanth, "Some engineering aspects of solid-state fermentation," Biochemical Engineering Journal, vol. 13, no. 2-3, pp. 127-135, 2003.

[41] K. Kovacs, S. Macrelli, G. Szakacs, and G. Zacchi, "Enzymatic hydrolysis of steam-pretreated lignocellulosic materials with Trichoderma atroviride enzymes produced in-house," Biotechnology for Biofuels, vol. 2, article 14, 2009.

[42] A. P. de Souza, D. C. C. Leite, S. Pattahil, M. G. Hahn, and M. S. Buckeridge, "Composition and structure of sugarcane cell wall polysaccharides: implications for second-generation bioethanol production," Bioenergy Research. In press.

[43] L. M. F. Gottschalk, R. A. Oliveira, and E. P. D. S. Bon, "Cellulases, xylanases, $\beta$-glucosidase and ferulic acid esterase produced by Trichoderma and Aspergillus act synergistically in the hydrolysis of sugarcane bagasse," Biochemical Engineering Journal, vol. 51, no. 1-2, pp. 72-78, 2010. 

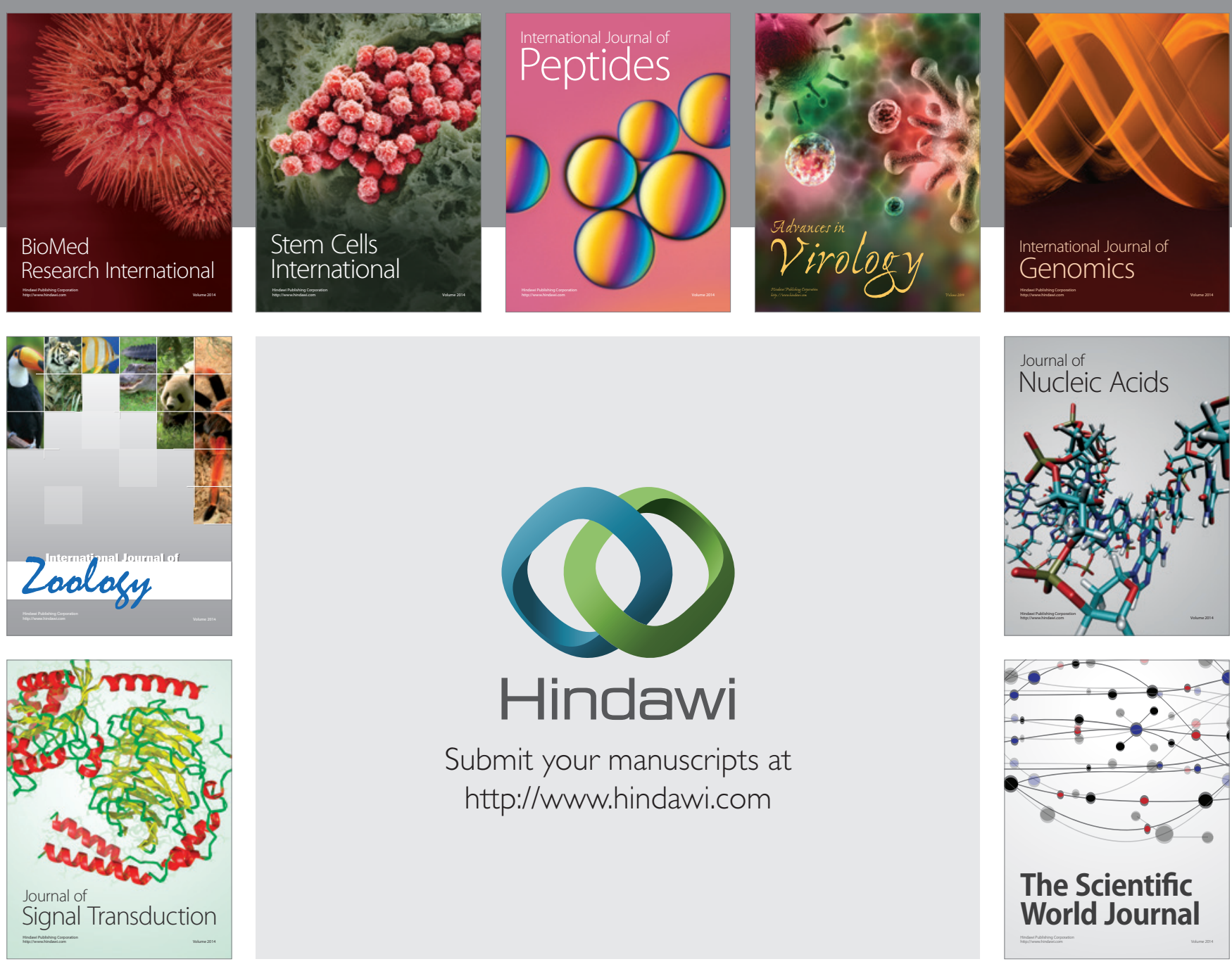

Submit your manuscripts at

http://www.hindawi.com
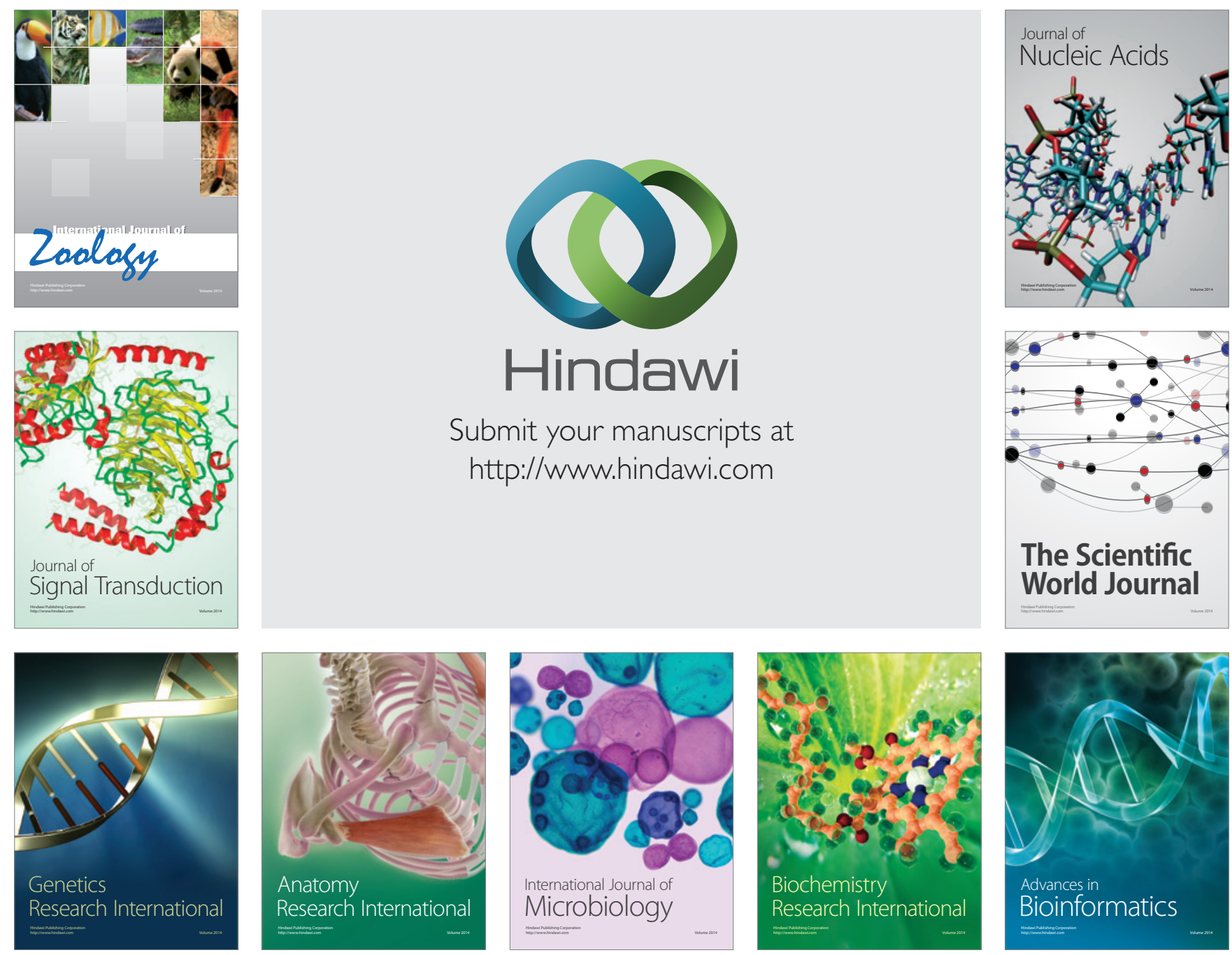

The Scientific World Journal
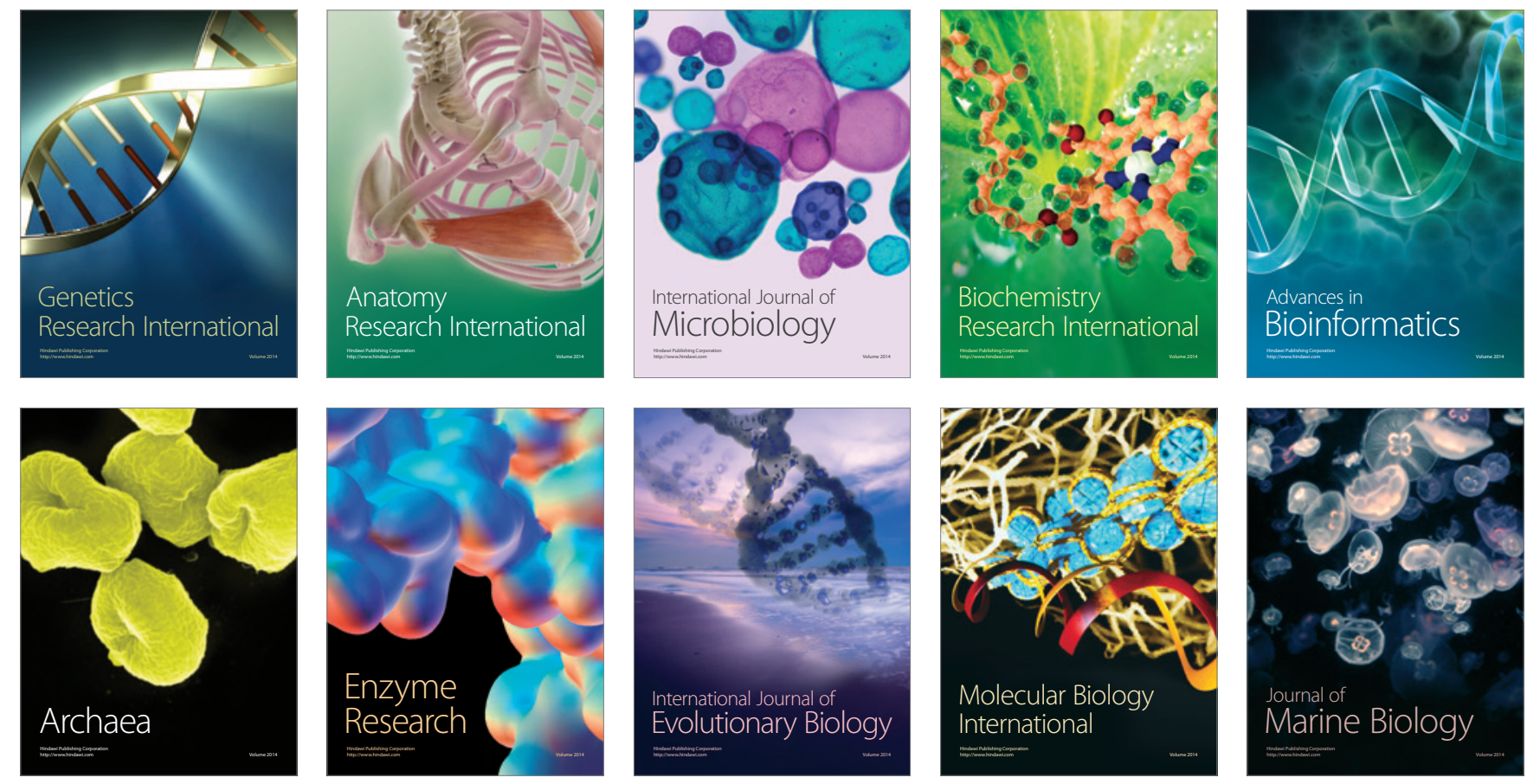